\title{
Descriptive Experiences on Photojournalism Practice: A Cross River and Akwa Ibom States' Confession
}

\author{
Ndoma J. Brown \\ Department of Mass Communication, Faculty of Communication Technology \\ Cross River University of Technology, Calabar, Cross River State, Nigeria \\ E-mail: ndomabrown@gmail.com
}

\section{Doi:10.5901/mjss.2013.v4n13p571}

\begin{abstract}
This study sets out to examine personal challenges and prospects of photojournalism practice in Nigeria. The study was basically extracted from personal experiences of photojournalists in Cross River and Akwa Ibom states; believing these parts of Nigeria have been neglected and voiceless on steaming issues concerning photojournalism in the practice of print media reportage. Apart from the identified problem of negligence, it has produced a low patronage of professionals in the practice and by such applicable standards affected readership interest. Given a serious or greater deal of attention compared to the high presence of photojournalists in other states. In such an impasse, readership consumption mix is found at a cross roads. Hypothetically, five qualitative interview research questions through the researcher's personal effort and telephone calls were carried out. Findings attributed their challenges to lack of interest in the profession, poor technological exposure, assault and unfair treatment meted on the photojournalists or the photojournalists' lack of apprehending creativity to express news through pictures. The simple random technique was employed in selecting three (3) photojournalists from Calabar Municipality in Cross River and five (5) in Uyo city in Akwa Ibom states. The researcher's effort discovered that yellow journalism was in the increase as it is related to some level of lopsided reports, geared towards dwindling effective professionalism. These enabling efforts will rescue commendable memories in photojournalism as attracting more interest to their photo messages. The prospects of Nigeria's photojournalism from Cross River and Akwa Ibom states' confession lie in fine-tuning the attitude of the managers of press houses in accepting the photojournalist as a visual reporter, irrespective of their glaring challenges.
\end{abstract}

Keywords: expressiveness, journalistic truce, story tellers, yellow journalism and professionalization of journalism.

\section{Introduction}

Photojournalism is highly in-expendable in investigative journalism. Investigative reporting, especially for the print media, is not all about investigating and writing stories. Investigative photographs are also sought for, recorded and documented to spice up the flavour of a story. The process of capturing images or what could be described as investigative photographs is what has necessitated the study of the all-important art of photography. A practical knowledge of elements of photography will definitely facilitate the work of an investigative reporter, (Nwabueze, 146). Great quantity of our Nigerian history has it that journalism started from Calabar in Cross River State. Oso et al., repositioned the historical account of publishing in Nigeria as revolving around the missionary, colonial administration and anti-colonial struggle. The history of publishing in Nigeria can be traced therefore, to the first press in Nigeria, which the Presbyterian Mission established in Calabar in 1846. The press was set up with the primary aim of providing Christian literature to the new converts (19). Worthy of note, Creek Town, Odukpani in Cross River State, has always been documented as the first seat in history that stopped the killing of twins. This, was vanguard by Mary Slessor.

\section{Research Design}

The research design employed in this research was descriptive survey research and qualitative design. Descriptive research was adopted and considered appropriate for this study because it focused on the observation and perception of existing situation. It describes and interprets what was concerned with issues, views and attitudes. Furthermore, the study dealt with processes that were going on and trends, which are developing within the confines of photojournalism practice and print media reports. The qualitative research approach was used in this research. The qualitative research relied on views and experiences of respondents who were direct participants in the study. 


\section{Study Area}

The study areas were Calabar Municipality and Uyo city Cross River and Akwa Ibom states respectively. These states are located in the South - Eastern zone of the Federal Republic of Nigeria and within the rain forest region. The states lie between latitude $5^{0} 32^{\prime}$ and $4^{\circ} 27^{\prime}$ North of the equator, latitude $7^{\circ} 28^{\prime}$ East of the Greenwich Meridian. As among the thirty-six states of the Federal Republic of Nigeria, the two states consist of thirty-one and eighteen local government areas in Akwa Ibom and Cross River. The two states cover a land mass of over 50,074,425 square kilometres with a population of over 5.6 million (Erim, 43). Calabar Municipality is the capital city of Cross River and Uyo city is the state capital of Akwa Ibom state. Both states are recognized for their inviting Calabar carnival festivals and tourism attractions.

Majority of the inhabitants of the states are civil servants making the states a civil service with some people predominantly farmers, petty traders, fishermen, craft-makers, tailors and hunters. In the practice of Christianity, the people in these areas are predominantly Christians, although with a few atheist and traditional African religion practitioners. The major ethnic groups are the Efiks, Ibibio, Annang, Ejagham and Bete speaking people of Northern Cross River.

Educationally, the two states have many pre-primary, secondary schools and tertiary institutions such as colleges of education, polytechnics, and universities respectively. In the areas of communication and advertising, there are existing media houses - both privately and government owned media that provide avenues for consumers and other business people within and outside the states.

Both states have tremendously been liberal and highly favoured with all the aggrandizements of tourism. There is presence of three and five stars hotels, quality eateries, refined bakeries and exotic tourist sites. In the area of print media journalism, there are: Cross River - The Nigerian Chronicle (governmentally owned), The Median and The Defender (privately owned). Akwa Ibom state: The Pioneer (governmentally owned), The Sensor, Update, Community Pulse, Insight, The sermon, NewsLine Express, Vintage Express, The Road, The Shield, News Net, News Link, Sky Net, Agenda, Providence, Daily News Wire, Coastal Times, Gazette, Golden Times, Torch, La-Vision, The Guide, The Waves, Verbatim, Franchise, Prime Time etc. and one privately owned magazine Dreams Alive (celebrity magazine).

\section{Past Condition}

Historically, photojournalism has resided somewhere between reportage, the delivery of information, and individual interpretation. Its effectiveness relies on a strong public platform and powerful modes of distribution. For decades its capacity has been linked to mass media, particularly print, because of its potential to reach large audiences in a credible manner. From the 1920's into the late 1960's print-based photojournalism strongly influenced public opinion (Watriss, online). Again, when non-professionals are brought into the profession, especially in Government owned newspaper houses, where nepotism reigns supreme, it only help in diminishing the quality of the paper. There is a popular saying amongst us. It is said that good photojournalist makes good appearance for the newspapers and magazines. Imagine newspapers and magazines without an eye catching photograph.

Photography as a profession; is one of the oldest imported professions practiced by indigenous Nigerians. This very important fact should make every photographer in Nigeria proud to belong to such an old and noble profession. Photography is also a profession which has served and, continues to serve Nigeria and millions of its various people extremely well! Photography continues to play a prominent role as a medium for art, culture and history. The role of photography in documenting the history and growth of Nigeria as an independent nation was well documented in a huge photography exhibition put up by the National Gallery of Art-NGA, Abuja, in October 2010; as part of the celebrations of Nigeria at 50. The photographic documentation of all spheres of cultural, industrial, agricultural, sports, and political, religious and infrastructural activities provided the most appropriate platform to visually assess and appreciate Nigeria's steady journey of progress and development since her independence from Britain in 1960. The National Gallery of Art's Photography Exhibition in Abuja in 2010 was a practical demonstration of the time-tested adage that indeed photographs is well worth thousands of words. At the exhibition school children in particular and people of various ages, sexes and ethnic groups were able to see for themselves the various facets of Nigeria's journey as a nation of diverse characteristics, since 1960, (photography, online).

It is very pertinent to point out that the various genres of photography are equally proficient in documenting both culture and history. Be it sports, news, documentary, art or fashion photography, the medium of photography is visually powerful and all-encompassing in delivering these messages. Hence, it was once said that photographs do not lie. This view though, is no longer wholly true, but photographs still remain a faithful means of documentation and expression. In 
this respect, people should continue to pay tribute to the thousands of photographers in Nigeria; including those responsible for the images in the NGA's exhibitions; who have contributed so much to giving permanent visual images of the nation Nigeria and, millions of her people.

It is said that you must know one's past to fully appreciate one's present and, better plan for one's future. In this regard, it is imperative for photographers in Nigeria to know the history of photography in Nigeria, as well as identify the pioneer indigenous photographers who have laid the solid foundation and charted the path for the growth and development of photography in Nigeria.

\section{Present Situation}

Today the Internet-with its larger reach, more rapid delivery, cheaper cost, and interactivity - challenges both prints and broadcast media. It is decentralized, open, inclusive and versatile. It has disrupted everything, including how photojournalists are paid. It is forcing photojournalists to find new outlets to present their work. Today, however, unlike 30 years ago when serious picture magazines started to fail, the Internet offers more opportunities and platforms for 'citizenphotojournalism'.

On the other hand, it is the very democratic nature of the Internet that poses a serious challenge to photojournalism. Without any accepted vetting of online information and pictures, it can be time-consuming and difficult to determine what can be trusted or how to read the information one finds. With amateur and ill-informed opinion as easily arrived at as more serious and responsible information, the idea of credibility is being uprooted. This situation presents real difficulties for photojournalism because so much of its power has been connected to the credibility —and influenceof its source of distribution (Watriss, online).

\section{Challenging Experiences}

On Nigeria's reportorial platforms like the newspapers, magazines and the internet, the unethical practice of photojournalism may be less controversial apart from some activities perpetrated by practitioners of citizen journalism. Citizen journalists include all those who practice the art of gathering and reporting news, both in writing and in pictures. Citizen journalism is made possible by one's access to reportorial platforms as it is common on the internet using the mobile phones in Nigeria. The inexperience of practitioners under citizenship journalism negates professionalism in the entire journalism practice which upholds respect for truth and the public's right to information which is fundamental principle of the profession (Obijiofor, online). It is also worthy to note that, print media outfits are often in the habit of using published or culling photographs from the net, that is why it is advisable that a certain level of ethical citizen journalism should be admonished.

\section{Interview Extracts}

\subsection{Presentation and Analyses of Interviews}

\subsubsection{Interview 1}

On Non-Professionals in the Profession, the participation of non-professionals in the practice of photojournalism is on the increase especially with the availability and opportunities created by the digital camera which are affordable and relatively easy to operate. They parade the cities with complimentary cards bearing names of different organizations, deceiving and defrauding unsuspecting public figures. It is hard to find out their true status because with the proliferation of print media institutions in Nigeria, most of them claim to be freelancing and verification is almost impossible. This has brought disrespect to the profession. Again, nepotism and tribalism are the basis for employing photojournalists into some media operatives at the expense of professionalism. This rather diminishes the quality of pictorial reports.

On Readiness to Learn, most photojournalists do not even have the passion to learn on the job. Consequently, most print reportorial media do not exist at their best in this digital era because most of the photographs used on the pages of print are non-expressive and lack that creative touch. Excellent skills are needed to combine with good camera and other equipment for quality and creative photographs but most times managements of such organizations do not even give attention to such photojournalist's needs.

On Harassment of Photojournalists, assault has become the daily bread of the photojournalist in Nigeria in his line 
of duty. Assaults and threats come mostly from losing teams in football and frustrated politicians of the opposing party. Generally, public figures and celebrities who feel their rights to privacy should be respected will harass the photojournalist.

On Creativity and Expressiveness, most Nigerian print reportorial media like The Guardian, The Nation and The Punch, rank tops and are doing well, while in the world of magazines, Ovation is striving. In that regard... it calls for constant replacement of cameras and other equipment in-order to maintain a communicable picture quality. And notably in this digital era, one expects the best from the print media. But what I observe today is a little above $45 \%$, because a great percentage of Nigerian photojournalists are ill equipped. And again, media houses never consider sending their photojournalists for fresher courses abroad, and most of us are lacking in modern ideas. Employing poorly equipped and untrained photographers cannot erase standards. Quantity cannot be substituted with quality.

On Recommendation, every photojournalist in Nigeria must be a registered member of the Nigerian Union of Journalists (NUJ). NUJ should rise up to protect and fight for any photojournalist, unjustly assaulted. There pay package should be improved upon for all photojournalists, together with several allowances and a deserved holiday. Employers should train and re-train their photojournalists. And finally; that the take home pay of most photojournalists is hardly enough to take them home.

\subsubsection{Interview 2}

On Non-Professionals in the Profession; this invasion has had a devastating blow on true photojournalism. Their negative or shabbiest reportorial styles as journalism give us a bad image. This is really an overt rape on the practice. Some nonprofessionals have crept into the profession through the back doors. Imagine the callous attitudes of civic photojournalism.

On Readiness to Learn, photojournalistic practice in Nigeria is rated on an average scale. Challenges of photojournalism's professional practice include lack of funds to purchase equipment and better or standard printing machines. For freelance photojournalist, lack of finance could be responsible for his use of less sophisticated equipment. But for newspaper organisations, insensitivity on the part of management is sometime responsible for this. The implication of all these, are resulted in poor output and sometimes endangered security to life of the practitioners. A bad tool will always increase one's problem.

On Harassment of Photojournalists, lack of regular training. Training of journalists and members understanding of codes of ethics can save them harassments and assaults.

On Creativity and Expressiveness, lack of creativity affects negatively, the overall output of the print reportorial media. Sometime gives a wrong to news both in the pictorial and news story. It always fair to be straight in your reportorial skill as to avoid double edge meaning to particular news.

On recommendation, the photojournalist's poor pay is a problem in the profession. Use of technology and organization's adherence to the demands of the Freedom of Information Bill can reduce harassment of photojournalist.

\subsubsection{Interview 3}

On Non-Professionals in the Profession, this is an abuse to the profession and capable of diminishing professional standards.

On Readiness to Learn, non-professionals are not doing much to learn fast.

Photojournalism practice is rated on the average in Nigeria. More constant and professional seminars, conferences and courses in photojournalism should be exposed to them.

On Harassment of Photojournalists, use of less advanced cameras for professional duties is due to the adamant position of the management of the print reportorial institutions and leads to deformation of image and character.

On Creativity and Expressiveness, also good digital cameras may be expensive to purchase. Institutions should encourage the use of standard cameras. The photojournalist works round the clock as such his camera must be up and doing in capturing the best news for reporting.

On Recommendation, all photojournalists should receive training in Journalism from approved institutions. Laws should be enacted to protect certified journalists on assignment. Given the right orientation and atmosphere, the Nigerian photojournalists will improve professionally. Photo-journalists are highly under paid despite the skills acquired and the risk involved. 


\subsubsection{Interview 4}

On Non-Professionals in the Profession, the practice of non-professionals in photojournalism makes the profession unattractive. Non-professionals who are practicing already are learning very fast while the profession is rated on average.

On Readiness to Learn, there are no funds to acquire more advanced cameras and equipment for photographers and it leads to poor outputs.

On Harassment of Photojournalists, harassment of journalists and poor wages for photojournalists brings about discouragement in the practice of the profession.

On Creativity and Expressiveness, however, creativity and expressiveness of journalistic photos used by the print media in Nigeria shows that there could be more improvement, if better orientation is given to the practitioners. We must understand that taking good pictures is like writing good news stories. But with a less sophisticated camera, one may not achieve this. You may have the best skills in photojournalism but without a good professional camera, you may be rated amongst the amateurs. Various locations call for various lenses and lens filters. Hence a photojournalist MUST always go to assignments with various lenses, batteries and an extra camera in case the unexpected occurs. Poor photo equipments are sometimes responsible for poor quality photographs on the pages of our papers.

On Recommendation, for an ultimate achievement of professionalism, photojournalists should seek more knowledge on ethical issues protecting their rights and should be charged to court, instead of downgrading the profession. Better pay packages should be bargained for and given to photojournalists, to bring their best out.

\subsubsection{Interview 5}

On Non-Professionals in the Profession, practicing in photojournalism lower standards, but performances of photojournalism in Nigeria can be rated slightly above average. Economic factors are responsible for the use of less sophisticated cameras among trained photojournalists in Nigeria.

On Readiness to Learn, the implication of using less advanced equipment in photojournalism practice may result to poor motivation and hence leads to poor learning output. Photojournalists need increased training and equipped seasonal conference sessions.

On Harassment of Photojournalists, issues of assault and harassments on photojournalists should be handled legally.

On Creativity and Expressiveness, the pay packages of photojournalists are quite poor but creativity is however not significantly affected as it strives a little above average. Photojournalists are not well remunerated and such factor; including assault on practitioners have the tendency to collectively affect the quality assurance in the profession.

On Recommendation, newspaper and magazine outfits should put in more efforts to motivate the journalists and the photojournalists. The Nigerian Union of Journalists is the umbrella that covers every journalist. The union should rise up whenever any of her members is assaulted in the course of his or her duty, just like they did in the case of Minere Amakiri, the Port Harcourt correspondent of the Nigerian Observer, in the 80's during the military era. We all know that human's want is insatiable. Far from this, my work as a photojournalist is hazardous and time consuming. The security operatives are almost always looking at your movements or searching your bag. At the airport, you are not allowed to travel with your flash gun batteries, at the scene of events, the policemen pushes you all around. Pick pockets are after your money or cell phones. We travel at odd times. We miss our families a lot. There's nothing like privacy for a photojournalist, especially when the editor needs you most. One deserves a good pay package, including several allowances and a well deserved holiday at the expense of one's employer.

\subsubsection{Interview 6}

On Non-Professionals in the Profession, there is a high involvement of non-professionals in the practice of photojournalism and there seems to be no control measures over such recalcitrance.

On Readiness to Learn, the non-professionals who are amateurs are not even learning on the job and would need academic and practical learning. The practice of photojournalism in Nigeria can be rated above average even as poor equipments are used.

On Harassment of Photojournalists, there is an issue of poor pay packages for journalists and harassments/assaults on them.

On Creativity and Expressiveness, creativity and expressiveness of the photos are good especially in some 
leading national dailies. Averagely practicing or intended practitioners of photojournalism should possess a B.Sc or HND in journalism. Most of the people who gate crash into the profession are not willing to learn. Apart from the passion and willingness to learn on the job, a good photojournalist must have a third eye for the unusualness. He always looks for scoops, and always willing to learn new things. His camera is his companion. These qualities, a non-professional cannot boast of. And so he cannot give what he does not have, hence, diminishing standard in the profession crawls in.

On Recommendation, a special law to protect journalists from assaults should be enacted. A combination of factors such as poor remuneration and lack of creativity can affect the practice of journalism in Nigeria.

\subsubsection{Interview 7}

On Non-Professionals in the Profession, the involvement of non-professionals in photojournalism lowers standards and constitutes unprofessional conduct and most of them do not want to learn.

On Readiness to Learn, however, the practice of photojournalism has improved tremendously above average. Take note, there is a great difference between availability and wiliness to learn.

On Harassment of Photojournalists, a law should be enacted to check assaults and unfair treatment on photojournalists. A combination of factors can challenge good quality of photographs for reports. There is notable improvement in the practice of the profession.

On Creativity and Expressiveness, most photojournalists are creative and should be encouraged to perform better. To achieve professionalism, all journalists should uphold and maintain ethical standards set by their organization.

On Recommendation, use of less advanced cameras lower picture quality for better news dissemination. The advanced cameras are expensive which only the managements of the photojournalists can afford. Remuneration for photojournalist is very poor.

\subsubsection{Interview 8}

On Non-Professionals in the Profession, the practice of photojournalism should not be limited to professionals only.

On Readiness to Learn, those who are practicing without professional training are learning very fast while general practice is rated slightly above average. Less advanced equipments are used because they are available and affordable.

On Harassment of Photojournalists, offenders (i.e. those who assault photojournalists) should be sanctioned. Harassment and assault on photojournalist is alarming while pay package is fairly poor. There should be improved packages for photojournalists.

On Creativity and Expressiveness, Creativity and expressiveness of journalistic photos is improving. Photojournalists and other practitioners need training. Talking about creativity and expressiveness, in some of the notable independent papers readily come to mind are The Guardian, Nation and The Punch newspapers that stands out in ranking. A photo that is dormant is an assault on a newspaper. A good illustrative and news telling picture will generate readers' interest. These are the reason these papers are a must read for the print media consumers. Many of our newspapers are grey because of the failure to obtain and use lively pictures. That is where photojournalism comes in. In Nigeria where there is a high degree of illiteracy, pictures tell the stories more than words. This accounts for the great sales of photo studded magazines like the Ovation magazine in Nigeria.

On Recommendation, a number of factors negatively affect photojournalism practice including output quality but solutions to the problems can make for a better profession.

\section{Discussion of Findings}

The primary objective of the interview was to share the experiences of practicing journalists and photojournalists on issues of professionalism, brutality and assault on photojournalists and creativity in photojournalism. This was intended to bridge the gap in understanding the significant relationship between practical issues and their impact on good and effective photojournalism. Participants were asked to comment on the impact of quacks and untrained practitioners on the practice of photojournalism. Findings unanimously indicated that non-professionals abound in the practice of photojournalism. Some practitioners of this sort found themselves in the profession because they could afford the camera and other equipment to operate. However, their involvement in the trade is viewed as a threat that is capable of inviting disrespect to the profession. To others, the involvement of quacks can only lower standards in the profession.

The reasons for employment of quacks in the practice of photojournalism range from giving the jobs to people 
without any prior knowledge to the trade and no form of training and readiness to learn, to one's ability of owning a camera. Despite the presence of quacks, findings show that practitioners, whether amateurs or professionals, have been practicing photojournalism above average. This is an indication that apart from affording the camera, individuals have some inborn skills that may be untrained, but when harnessed, would leap in bounds the developmental point of no return.

Lack of funds, either on the part of government, or the journalists, to afford advanced cameras for usage is another challenge against effective professionalism. Managements of institutions where the journalists work may not even understand the relevance of acquiring more advanced cameras for coverage by their photojournalists. Besides, the study confirms from participants that harassments and assaults on photojournalists are inherent while questions or poor pay is left unattended to. This study has established that the inherence of all issues like harassments, assaults and poor remunerations constitute a giant factor that would continue to witness the challenge of effective photojournalism practice. Thus, other factors like poor pay and harassment of journalists, above all may not spoil the creativity in the practice. It implies that the absence of one cannot be harmful, but the combination of all these factors can significantly affect the practice of photojournalism.

Simply put; training and retraining of photojournalists, paying them good remuneration and enacting laws that guide against brutal treatment of journalists in the course of performing their duties. The training of photojournalists should be done in training institutions, certificates issued to grandaunts and their names entered on the list of Photojournalists Association of Nigeria.

\section{Theoretical Framework}

The Nigerian society allows room for civic journalism, where every bona-fide member is permitted to contribute to any available news of his interest. This sort makes provision for yellow journalism, whereby any owner of a camera is allowed to summit sensational photographs to a newspaper or any other media house for publication. William Randolph Hearst (1896), a prominent proponent of yellow journalism. He demonstrated that the news business could be profitable. One secret to his success was devising better strategies for luring low-income readers. His newspapers combined a lowselling price with innovative new forms of content that included lots of pictures, serialised stories and comic strips, Baran and Davis, (46). Yellow journalism, provided most media practitioners (photojournalists) caring very little for the niceties of accuracy, objectivity, and public sensitivity, Baran and Davis, (96).

As resounding efforts made by Photojournalists Association of Nigeria (PJAN), Nigeria Union of Journalists (NUJ), concerning uncensored attitudes attached to the practice of photojournalism, it became expedient to apply one of the normative theories called "Professionalization of Journalism." As pressure for government regulation of media mounted, industry leaders and media practitioners responded with efforts to professionalize their conducts. Joseph Pulitzer and William Randolph Hearst established professional awards. The industry lobbied for and subsidized the establishment of professional schools to train media practitioners. Rather than cede control of media to a government agency, media managers went on record with pledges to serve public needs. Industry codes of ethics began to formalize another important conception about the role of the media - that of a watchdog guarding the welfare of the public as effectively as possibly, Baran and Davis, (108). This is exactly the same dose that the photojournalists and media practitioners in Cross River and Akwa Ibom states should be using as rare opportunities in advocating on the fact that there should be a sincere check, since the public's trust has been placed in the palms of the photojournalists.

\section{Conclusion and Future Expectations}

Photojournalism in Nigeria has come to stay, no matter the grievances and challenges experienced by the photojournalists in the course of executing their official responsibilities, there will always be a reason to tell stories in pictures. Exploitative tendencies of most media proprietors, brings about poor remuneration and this also leads to the employment of unprofessional hands, hence, the ineffectiveness in the practice of photojournalism in Nigeria. A good pay will attract the best hands into the profession and the result will be in the positive. Photojournalism practice in Calabar Municipality and Uyo city, by inference Cross River and Akwa Ibom states in Nigeria, through this descriptive research is still below average.

Adequate training leads to perfection. The question is, where can one get this training as a photojournalist in Nigeria? Which higher institution in Nigeria offers a full fledge course in photojournalism? How many employers are willingly ready to train their photographers abroad, where these training are available? Until these questions are truly 
answered and acted upon, we will remain where we are.

\section{References}

Baran, Stanley J. and Davis, Dennis K. (2007). Mass Communication: Foundations, Ferment and Future, $4^{\text {th }}$ ed. India: Anubha Printers Erim, E. O. (1990). "The Upper Cross Region: Early Migrations and Settlement" in A History of the Cross River Region of Nigeria, Abasiattai, M. (ed). Calabar: University of Calabar Press.

Nwabueze, Chinenye. (2012). The Art of Investigative Reporting: A Practical Guide, 2nd ed. Imo: Topshelve Publishers.

Obijiofor, Levi. (2002, June 14). "Ethics and the Photojournalist." The Guardian. Friday, www.ngrguardiannews.com

Oso, Lai; Osunbiyi, Bidemi and Biobaku, Lanre. (2009). Book Publishing: A Practical Guide. London: African Resource International

Photography. (2013, January 9). blogger http://www.diamondpublicationsng.com/diamondpublications/mediarw2012/mediarwapr12 /photographytxtapr12.php

Watriss, Wendy. (2013, January 6). http://www.nieman.harvard.edu/reports/article/102074/Steps-Learned-Along-the-Way-RedefiningPhotojournalisms-Power.aspx.

\section{Appendixes on Interview Schedule}

\section{Interviewee 1:}

Name: Anthony Edet Omin

Organizational Affiliation: CRS Government House Press, Calabar. State of Resident: Cross River. Position: Principal Photo-journalist

Years of Experience: 36 years. Formal Training: Nigerian Institute of Journalism, (N.I.J), Egba, Lagos

Qualification: Certificate in Photo-journalism

Date, Time and Location: The interview was personally conducted by the researcher on the 12th February, 2013, by 2: 36 p.m; The Government Press, Governor's Office, Cross River State.

\section{Interviewee 2:}

Name: Francis Okon Nsisuk

Organizational Affiliation: Nigerian Watch newspaper. State of Resident: Cross River. Position: Photojournalist (Photo Editor)

Years of Experience: 17 years. Formal Training: International Institute of Journalism, Abuja (1998), Nigerian Institute of Journalism, Lagos (2000)

Qualification: Certificates in Photojournalism.

Date, Time and Location: The interview was conducted by the researcher on the 14th February, 2013, by 4:23p.m; NUJ Secretariat, (Earnest Bassey Etim), Cross River State Chapter, State Housing Estate Calabar.

\section{Interviewee 3:}

Name: Daniel William

Organizational Affiliation: MofiNews magazine. State of Resident: Cross River. Position: Photojournalist

Years of Experience: 6 years. Formal Training: Advertising Graphics

Qualification: B.Sc Mass Communication (in view)

Date, Time and Location: The interview was carried out by the researcher on the 19th February, 2013, by 3: 38p.m; Cross River State Ministry of Finance, Calabar Municipality, Cross River State.

\section{Interviewee 4:}

Name: Inemesit Udofia

Organizational Affiliation: The Guardian newspaper. State of Resident: Akwa Ibom. Position: Press Photographer Years of Experience: 15 years. Formal Training in Photojournalism: Print Journalism

Qualification: BA (Hons) Communication Arts

Date, Time and Location: The interview was on the 20th June, 2013, at 3:24 p.m, Correspondents' Chapel, No. 13 
Asutan Street, Uyo, Akwa Ibom State

Interviewee 5:

Name: Ernest John Ikot-Iko

Organizational Affiliation: Fresh Facts newspapers. State of Resident: Akwa Ibom. Position: Senior Photographer Years of Experience: 26 years. Formal Training: Photojournalism and Certificate in Videography

Qualification: HND - Mass Communication

Date, Time and Location: The interview was on the 20th June, 2013, at 4:04 p.m, Correspondents' Chapel, No. 13 Asutan Street, Uyo, Akwa Ibom State.

\section{Interviewee 6:}

Name: Emeka Samuel

Organizational Affiliation: The Road, newspaper. State of Resident: Akwa Ibom. Position: Photojournalist Years of Experience: 11 years. Formal Training: Yes

Qualification: B. Sc Mass Communication

Date, Time and Location: The interview was on the 22th June, 2013, at 12:08 p.m, Correspondents' Chapel, No. 13 Asutan Street, Uyo, Akwa Ibom State.

\section{Interviewee 7:}

Name: Aniefiok Udo-Nquak

Organizational Affiliation: BusinessDay newspaper. State of Resident: Akwa Ibom. Position: Press Photographer Years of Experience: 30 years Formal Training: Yes.

Qualification: Certificate in Photojournalism

Date, Time and Location: The interview was on the 22nd June, 2013, at 3:23 p.m, Correspondents' Chapel, No. 13 Asutan Street, Uyo, Akwa Ibom State.

\section{Interviewee 8:}

Name: Ene-Obong Emmanuel Akpan

Organizational Affiliation: Vintage Express newspaper. State of Resident: Akwa Ibom. Position: Photojournalist Years of Experience: 19 years. Formal Training: Printing Technology

Qualification: HND - Mass Communication

Date, Time and Location: The interview was on the 23nd June, 2013, at 11:12 a.m, Vintage Express office, 21 Okon Essien Street, Uyo, Akwa Ibom State. 
